Mojca Cajnko*

\title{
Politeness in Hittite state correspondence: Address and self-presentation
}

DOI 10.1515/pr-2016-0006

\begin{abstract}
In this paper deferential and strategic or face-based politeness are distinguished (Jucker 2010). The distinction seems to be crucial for a proper understanding of the use of address and self-presentation terms and the address formula in Hittite state correspondence. Namely, the corpus of 80 letters written between c. 1450 and 1190 B.C. shows that the appropriate use of politeness largely reflects the writer's awareness of his place in society, as well as his desire to behave in conformity with culturally expected forms of behavior. Examples of deferential politeness are thus influenced by the relative and absolute social status of communication participants as well as general and socially expected concern for the addressee's face. Examples of real strategic politeness may be observed in symmetric relations where the writer is trying to minimalize a potentially face-threatening act and in some letters to the Hittite king.
\end{abstract}

Keywords: Hittite, address, self-presentation, deferential, strategic politeness

\section{Introduction}

The starting point of this research is the supposition that the purpose of language use lies in social interaction and the creation of communicative relations. Interpersonal communication is an interactive and dynamic process in which interlocutors strive for the optimal achievement of their communicative goals. They achieve these goals by using linguistic expressions and communicative strategies suited to the given situation. Their choice is determined and ratified by social conventions and individuals' pragmatic information (see Dik 1997). Interpersonal communication is always socially indexing, as it reflects broader social circumstances and relations of social power, degrees of social distance or solidarity, the absolute or relative social status of the interactants and their level of education, gender, age, etc. (see Brown and Levinson 1987; Levinson

*Corresponding author: Mojca Cajnko, Ludwig-Maximilians-Universität München, Institut für Assyriologie und Hethitologie, 80539 München, Germany, E-mail: mojca.cajnko@gmail.com 
1994: 91-96; Fillmore 1997: 111-125; Kasper 1997). ${ }^{1}$ One important component of an individual's social image is his face. Brown and Levinson (1987: 61) define face as the public self-image that every adult member of society wants to claim for himself, which consists of two related aspects: negative face, that is, the basic claim to freedom of action and freedom from imposition and positive face, that is, the positive consistent self-image or "personality" claimed by interactants, a crucial aspect of which is the desire that this self-image be appreciated and approved of.

This paper will discuss politeness as a social practice and a key means by which humans work out and maintain interpersonal relationships (Kádár and Haugh 2013: 1-2). In line with Jucker (2010), two types of politeness will be distinguished here. Strategic or face-based politeness aims at conflict avoidance and reflects the speaker's desire to save, maintain and enhance the face of the addressee (in the sense described by Brown and Levinson 1987). Discernment politeness concerns the speaker's desire to conform to social conventions and maintain social relationships and can be observed in the use of appropriate and conventionalized linguistic forms. The distinction between strategic and discernment politeness may be crucial in societies where politeness and appropriateness often coincide in praxis. The presupposition of this study is that this distinction is also crucial for a description of referential terms. Namely, the use of such terms is deeply rooted in the social hierarchy and in individual social roles, but may also reflect the speaker's attitude (Nevala 2009). Reference terms therefore may or may not be strategically polite, depending on the social norms of a given culture, the context of the communication and the co-text of the utterance (see Watts 2005: xxxviii; Christie 2007; Mills 2011: 46-48).

This paper presents the Hittites, their corpus and the corpus of the research, followed by the purpose of the research. The main part is devoted to address and self-presentation terms in Hittite state correspondence as well as to the use of address formula. Their use is described in the framework of Jucker's 2010 research on politeness.

\section{The Hittites}

The first Indo-European state was located in central Anatolia between the $16^{\text {th }}$ century B.C. and the first or second decade of the $12^{\text {th }}$ century B.C. At the height

1 The social power of communication participants is defined on the basis of their relative positions in the social hierarchy, their ages, their gender, etc. Social distance or solidarity is defined on the basis of intimate relationships, shared experiences and opportunities, similar amounts of capital, etc. 
of its political and military might, the Hittites were on equal footing with ancient Egypt, as the truce between the Hittite king Hattušili III and pharaoh Ramses II dated to 1259 B.C. shows.

The Hittite corpus consists of approximately 30,000 fragments; ${ }^{2}$ clay tablets preserved in their entirety are rare. Once these fragments are joined and added to already known texts, the corpus will contain around 3,000 texts of various kinds. Most of the preserved tablets come from the archives in the Hittite capital Hattuša (today Boğazkale), and some come from the provincial centers at Maşathöyük, Kuşakli and Ortaköy and from sites outside the borders of the Hittite state, for example Ugarit and Tell el-Amarna in Egypt (see Klinger 2007: 27-28).

The Hittite texts were written in cuneiform script, variations of which were in use throughout Asia Minor from the $3^{\text {rd }}$ millennium to the $4^{\text {th }}$ century B.C. (Edzard 1976-1980: 565). According to van den Hout (2009), the Hittites initially used cuneiform to write Akkadian, ${ }^{3}$ a Semitic language (and lingua franca of the ancient Orient); systematic scribal activities in Hittite began at the start of the $15^{\text {th }}$ century B.C. and ended with the fall of the Hittite state in the first or second decade of the $12^{\text {th }}$ century B.C.

Texts in Hittite include written foreign language material within Hittite sentences (a large number of words, grammatical morphemes and derivative suffixes of Akkadian and Sumerian origin) ${ }^{4}$ or even longer passages (such as incantations or ritual formulas) in Hurrian, Luwian, Hattic and Palaic.

The oldest documents in an Indo-European language provide evidence of hierarchic organization within the Hittite state. The state gods function as the highest authority; the king (appointed by the gods) appears as a high priest, the supreme judge and a chief military commander. Beneath the king are the vassals, who have sworn an oath and are bound by treaties, as well as functionaries in the palace and temples, officers at the state borders and others. A similarly strict hierarchy appears in the framework of individual social classes

2 Košak, personal communication 29/11/2015.

3 The oldest records of the Hittite state in Akkadian date to the second half of the $17^{\text {th }}$ century B.C.

4 In line with conventions in Hittitology, in the transliterations below Sumerograms (that is, originally Sumerian language material) are written with upper case non-italic letters (ŠU 'hand'), Akkadograms (that is, originally Akkadian language material) are written with upper case italic letters (QATU 'hand'), and Hittite, Luwian, Hurrian, etc. material is written with

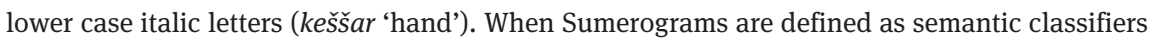
of a following (and rarely also a preceeding) word, they are written in superscript ( ${ }^{\mathrm{U}}$ ' $\mathrm{man}$ '), constituent parts of complex signs are marked with a dot or word space (DUMU.MUNUS.MEŠ (child.woman.PL) 'daughters'. 
(free, non-free and semi-free), occupational groups (the army, priests, scribes) and social groups (the royal family, see von Schuler 1957-1971; Beckman 1995).

Texts were preserved in the context of state administration and pertain to the oversight and management of the political, religious and economic life of the Hittite state. They were written by subjects of the King, that is, official scribes or officials with some scribal knowledge. These persons belonged to the dominant and upper classes of Hittite society and (presumably) were a minority within the Hittite population (Bryce 2002: 57); it is therefore only possible to study their social and linguistic norms within a relatively formal discourse.

\section{Hittite state correspondence and the corpus of the research}

Hittite state correspondence contains "the official correspondence carried on in the course of administrating the business of the king" (Hoffner 2009: 1). It pertains to the transport of grain or prisoners, legal matters, military intervention, oracular inquiries, etc. The only preserved "private" correspondence outside of the royal family is found in postscripts of official letters which officials exchanged among themselves (Weeden 2014: 49). Scribes would send greetings to their families and inquire after their health, promise help, quarrel about missing goods, personnel or slander, attempt to collect debts, etc. ${ }^{5}$ The main letters and postscripts are often written by different persons or addressed to different addressees, which indicates that the authors had to consider a broader audience than just the addressee. This implies that the writers consciously strived to follow the social and language norms of society when not dissuaded from doing so by other factors.

The form of these letters is highly conventionalized. They open with an address formula, which is often followed by greeting and well-wishing formulas and then by the body of the letter. There are no closing formulas which would serve as a kind of a farewell. Usually a horizontal line divides the parts. When a letter is followed by a postscript, the latter is set apart from the main letter by two horizontal lines (see Hoffner 2009: 56).

The following criteria affected the composition of the corpus used in the research: 1 . the participants of the communication are known; 2 . their absolute (king: scribe) or relative (superordinate: subordinate) social status is known;

5 In the rest of this paper, the letter 'a' marks the main letter, 'b' and 'c' the postscript(s). 
3. the time and broader historical context of the text is roughly known; 4. the texts are relatively well preserved. Efforts were also made to observe a single person (especially officials) in different communication circumstances, but the information offered by the Hittite corpus was mostly too limited to grasp the interactional history or dynamics of a particular situation.

State correspondence from the oldest period of the Hittite state, language and script has not been preserved (van den Hout 2009: 76). The corpus of the research thus consists of texts in Middle and New Hittite language ${ }^{6}$ written in the Middle, New and Late New scripts, ${ }^{7}$ dated between c. $1450-1190$ B.C. and found at the Hittite capital and various other sites. The bulk of the texts in the corpus derive from the provincial center Tapikka (today Maşathöyük) and were written in the span of a single generation (van den Hout 2007); they are dated to the Middle Script and the Middle Hittite language. This "imbalance" in the corpus is the result of the criteria for its composition. Although some prosographic studies of Hittite scribes and officials have been made (see Alp 1991; Beal 1992; Beckman 1995; Klinger 1995; Houwink ten Cate 1998; Marizza 2007; 2009; van den Hout 2007), the letters of Maşathöyük offer the most reliable and probably the most extensive published corpus for such a study.

The corpus includes 80 letters, 32 of which were sent by superiors and 24 by subordinates; in 24 letters the social relationship between the communication participants was symmetric (that is, roughly equal). 27 letters contain correspondence between the king and officials, 5 contain correspondence of the royal family and 48 contain correspondence between officials. ${ }^{8}$

\section{The purpose of the research}

To date, no systematic study of politeness in Hittite has been conducted. Most references to politeness phenomena rely on a lay understanding of politeness

6 For Old (1650-1450 B.C.), Middle (1450-1350 B.C.) and New Hittite language (1350-1190 B.C.) see Hoffner and Melchert 2008: xvii.

7 For Old (1650-1500 B.C.), Middle (1500-1350 B.C.), New (1350-1180 B.C.) and Late New Script (1240-1180 B.C.) see van den Hout (2008: 215).

8 Correspondence of superiors to subordinates: Bo 2810, KUB 23.85, KBo 18.2, Msk. 73.1097, HKM 2a, 3a, 6, 10a, 13, 14, 16, 17a, 19a, 21a, 22a, 26, 27a, 30a, 31a, 32, 36a, 53a, 54, 55?, 56b, 60a, 62a, 65a, 68, 73a. Correspondence of subordinates to superiors: KBo 9.82, 18.3, 18.54a, b, 18.95, Or. 90/800a, b, Güterbock 1979a, b, KuT 49, 50, HKM 17b, 27c, 29b, 33b, 36b, 46, 48, 51, 52b, 59, 60b, 62b, 81a. Correspondence of equals: HKM 2b, 3b, 10b, 17c, 19b, 21b, 22b, 27b, 28b, 30b, 31b, 52a, 53b, 56a, 58a, b, 63, 65b, 66, 71a?, 71b, 73b, 74, 81b, ABoT 65. The abbreviations ABoT (= Ankara Arkeoloji Müzesinde Bulunan Boğazköy Tabletleri), Bo (= Bogazköy Tablet), HKM (= Hethitische Keilschrifttafeln aus Maşat), KBo (= Keilschrifttexte aus Boghaz- 
and do not actually define the term. Treatments are also largely limited to Hittite letters, particularly to formulas and address terms. As the continuation of the paper will show, the Hittites followed the same strategies for addressing others and for self-presentation, and for this reason these terms need to be studied together. The aim of this research is therefore to elaborate on address and self-presentation terms in Hittite state correspondence and on the use of the address formula, which contains both types of terms. Another shortcoming of most interpretations is that they fail to take information in the body of the letters into account, and the paper also aims to remedy this situation.

\section{The address formula}

The address formula has only two possible realizations: the formula thus $x$ say to $y$ is used when addressing subordinates (1), and the formula say to $x$ thus $y$ is used in letters to superiors (2). When the social status of the communication participants is roughly one of equality, the sender usually precedes the addressee (3) (see Hagenbuchner 1989a: 40-47; Hoffner 2009: 57). Alp (1991: 5) noted that deviations from the standard pattern in correspondence with symmetric social relations (4) might be influenced by norms of politeness; Beal (1992: 464) has linked these deviations to requests for favors.

(1) UMMA ${ }^{\mathrm{D}} \mathrm{UTU}-\mathrm{S} I-M A \quad$ ANA ${ }^{\mathrm{m}}$ Kaššū $\quad$ QIBI-MA

thus ${ }^{\text {god }}$ Sun-stem $^{9}$-COP to manKaššū say-COP

'Thus His Majesty: Say to Kaššū ...'10

(2) $[$ AN]A BELI GAL MEŠEDI BELI-YA Q[IBI-MA U]MMA GAL

[t]o lord big guard lord-1SG.POSS s[ay-COP. T] hus big DUMU.MEŠ É.GAL ARAD-KA-MA

son.pl house.big servant-2SG.POSS-COP

'To the lord, the Chief of the Guards, my lord: thus Chief of the Palace Servants, your servant ...'11

köy), KUB (= Keilschrifturkunden aus Boghazköy), KuT (= Kuşakli), Msk. (= Meskene), Or. (= Ortaköy) refer to their cuneiform publication or inventory number.

9 The form ${ }^{D}$ UTU-ŠI can be further analysed into ${ }^{D}$ UTU-Š-I ${ }^{\text {god }}$ sun-stem-1SG-POSS. Since this is a petrified form in Hittite, I refer to it as a stem form.

10 HKM 6 1-2.

11 KBo 18.95 1-2. 
(3) UMMA ${ }^{\mathrm{m}}$ Kikarša ANA ${ }^{\mathrm{m}}$ Tahazzi-DINGIR-LIM ${ }^{12}$

thus manKikarša to manTahazzilli

ŠEŠ.DÜG.GA-YA QIBI-MA

brother.dear.gen.-1SG.POSS say-COP

'Thus Kikarša: Say to Tahazzili, my dear brother ...'13

(4) ANA ${ }^{\mathrm{m}}$ Himmu-DINGIR-LIM ŠEŠ.DÙG.GA-YA QIBI-MA UMMA

to manHimmuili brother.dear.gen.-1SG.POSS say-COP thus

m.GIŠGIDRU-DINGIR-LIM ŠEŠ-KA-MA

manHattušili brother-2SG.POSS-COP

'Say to Himmuili, my dear brother: Thus Hुattušili, your brother ...'14

In the corpus of the study eight examples are attested where the addressee precedes the sender in correspondence between equals (scribes/officials). Seven of these examples are found in postscripts. This unusual order is not used only in requests for favors, but more generally, when the writer is potentially threatening the negative face of the addressee. Namely, it is used when the writer is reassuring the addressee about the well-being of his family, ${ }^{15}$ confirming his help in legal matters, ${ }^{16}$ asking for some goods, ${ }^{17}$ complaining about the lack of greetings from the addressee ${ }^{18}$ or trying to influence the addressee's actions/opinions in some other way. ${ }^{19}$ In two of these examples the address term is also unusual, as the adjective dear is not used with the appellative brother $^{20}$ or only a name ${ }^{21}$ is used (see below). In seven examples an unusual self-presentation term is used. Namely, self-presentation with a name and the appellative your brother is used only when a deviation from the standard pattern occurs in the address formula, otherwise only a name is used. In seven letters an unusual form of the address formula is followed by greeting and/or well-wishing formulas, which should be interpreted as a deferentially polite and conventionalized feature of Hittite letters sent to superiors or equals (see Hoffner 2009: 63, 116, 245, 261; cf. Hagenbuchner 1989a: 84).

$12{ }^{\mathrm{m}}$ Tahazzi-DINGIR-LIM, ${ }^{\mathrm{m}}$ Himmu-DINGIR-LIM, m.GIš GIDRU-DINGIR-LIM, ${ }^{\mathrm{m} . D} \mathrm{U}-B E L I$ are rebus writings and will not be further analysed here.

13 HKM 58 1-2.

14 HKM 10b 1-2.

15 HKM 2b, 3b.

16 HKM $10 \mathrm{~b}$.

17 HKM 56a.

18 HKM 56a, 58b.

19 HKM 17c, 30b, 73b.

20 HKM 30b.

21 HKM 17b. 
In the Maşat corpus this atypical form of the formula is used in letters from five different writers addressed to three different addressees. With the exception of two letters, which Šurihili addressed to Uzzū, 22 this formula is not used consistently when addressing the same person. If the few letters from Hattušili to Himmuili ${ }^{23}$ and from Marešre to Uzzī ${ }^{24}$ allow for any conclusions, it seems that the use of this formula is connected to formal rather than personal requests.

In all examples the writer, regardless of his own subordinate or superordinate status in the interaction (cf. Nevala 2009: 253-254), seems to be emphasizing deference toward, (order of the formula), and solidarity with, the addressee (self-presentation) when performing a potentially face-threatening act. The use of the atypical address formula in symmetric relations therefore fits the concept of strategical politeness as described by Jucker (2010); it is influenced by the writer's positive attitude toward the addressee, as well as by the absolute ranking of the imposition (see Brown and Levinson 1987).

\section{Address forms}

In the address formula superiors were usually addressed with a title, the appellatives lord (BELU, EN) or lady (GAŠAN, BELTU) and the $1^{\text {st }}$ person possessive pronoun. This form of address was consistently used when officials addressed the Hittite king and queen. The king was not addressed by the title king (LUGAL), but by the title His Majesty, lit. My Sun-god (DUTU-ŠI). In other situations, superiors could be addressed with just a title, with a title and appellatives such as lord (Hagenbuchner 1989a: 46) or superior (lit. the first, MAHRU $\hat{\text { ) }}$ and with the $1^{\text {st }}$ person possessive pronoun (5). The use of personal names instead of titles ${ }^{25}$ or together with them ${ }^{26}$ is sporadically attested, but never for the royal couple.

Occasionally, the familial terms dear father (ABI DÙG.GA) or dear mother (AMA.DÙG.GA) and the $1^{\text {st }}$ person possessive pronoun are used to address superiors or older colleagues (Alp 1991: 303). According to Hoffner (2009: 59), the choice of the appellative father as opposed to lord, when not marking actual familial relations, is conditioned by close personal contact, such as the relation

22 HKM 2b, HKM 3b.

23 HKM 10b, 27b, 28b, 52a.

24 HKM 22b, 31b, 33b, 53b.

25 HKM 17b.

26 HKM 29b, HKM 52b. 
between a teacher and a pupil. According to this author the familial terms are used more often in the less formal body of the letters, while the opening lines contain appellatives such as my lord (see also Hagenbuchner 1989a: 15; Alp 1991: 98). On the basis of the corpus, it can be noted that familial terms are outfitted with names or appellatives of the type my lord or my superior in more conventionalized and formal opening lines, see (5), but are without them in the body of letters.

On other occasions, titles by themselves, ${ }^{27}$ appellatives by themselves, ${ }^{28}$ or combinations thereof, ${ }^{29}$ may be used in the body of the letters. The use of $2^{\text {nd }}$ person personal pronouns is consistently avoided when addressing the royal couple, and an appellative such as His Majesty, my lord is used instead; this seems to also be the norm when addressing other superiors (6).

In roughly symmetric relations a name, the appellatives dear brother (ŠEŠ.DÜG.GA) or dear sister (NIN.DÜG.GA) and the $1^{\text {st }}$ person possessive pronoun are used, see (3) and (4). High-ranking officials may only use titles (see (2) and Hagenbuchner 1989a: 45-46; Alp 1991: 4; Hoffner 2009: 58). Hoffner (2009: 59) believes that the adjective dear (DÙG.GA) could reflect a real familial relationship, but this view is not supported by the more extensive corpus used here (see Hagenbuchner 1989b; Alp 1991; Hoffner 2009). From the approximately 35 letters of state correspondence with equal interactants and preserved opening lines, only five lack the adjective dear; ${ }^{30}$ thus the use of the adjective dear in these circumstances seems to be the norm.

In the body of the letters, the appellative my dear brother and $2^{\text {nd }}$ person personal pronouns may be used. The former is typical of assertions of help or concern for the addressee or his family ${ }^{31}$ and also appears (but not consistently) in requests of a personal nature. ${ }^{32}$ Since the adjective dear is not used with appellatives that do not refer to familial relations, its use may be influenced by a wish to emphasize familiarity or in-group identification or, in the case of potentially face-threatening acts, by a wish to emphasize a positive attitude towards the addressee.

A subordinate was usually addressed by name. This occurs consistently in letters from the Hittite king to officials (1), whereas the queen is addressed by her title and the appellative my lady (see also Hagenbuchner 1989b: 2). The

27 Güterbock 1979a.

28 HKM 52b.

29 KBo 18.95.

30 HKM 30b, 70, KBo 18.35, 18.38, 18.96.

31 HKM 2b, 3b.

32 HKM 3b, 31b, 53b, 56a, 71b; the appellative does not appear in HKM 22b, 30b, 81b. 
king also uses the address my dear mother in real familial relationships. In royal correspondence the order of sender and addressee reflects the fact that the king outranks the queen and therefore appears first in the opening line (Hoffner 2009: 327). The king nonetheless shows deference to the queen, as he otherwise only uses the appellative my lady for goddesses (7). Rarely, the appellatives my dear son (DUMU.DÜG.GA-YA) 33 and, in extremely rare cases, my son (DUMU $=Y A)^{34}$ may be used. ${ }^{35}$ In the body of the letters, $2^{\text {nd }}$ person personal pronouns may also be used for addressing subordinates.

Generally, superiors (including the Hittite king) are addressed with a title and/or appellative and the verb is in the $2^{\text {nd }}$ person singular imperative form (6). In symmetric relations the simple use of the $2^{\text {nd }}$ person singular imperative form is common in requests, wishes, assertions, etc. and the appellative my dear brother may also be added ${ }^{36}$ to downgrade potentially face-threatening acts to a certain degree. These forms of address and their possible combinations are presented in the Table 1.

(5) A[NA BEL]I MAHRI-YA ABI DÙG.G[A-Y]A [QIBI-MA] UMMA

to lord superior-my father dea[r-m]y [say-COP] thus

${ }^{\mathrm{m}}$ Hašamili DUMU-KA-MA

manHašamili son-2.SG.POSS.-COP

'Say to lord, my superior, my dear father: Thus speaks Tarhunmiya, Hašamili, your son .... ${ }^{37}$

33 HKM 56b.

34 HKM 65. In Bo 2810 the king may be stressing the subordinate status of the addressee to secure the delivery of grain, which was delayed by the addressee.

35 The only attested instance of the appellative my dear daughter (DUMU.MUNUS.DÙG.GA= YA) in the letters published by Hagenbuchner (1989b), Alp (1991) and Hoffner (2009) is HKM 82, where this daughter is being addressed along with someone whom the writer calls my dear brother. In the state correspondence published by these authors the only female writer or addressee is the Hittite queen. Some evidence that other females, such as priestesses, could correspond independently exists (KuT 49) and one female name of a scribe (out of more than 200) is known (see Hoffner 2009: 7). In the corpus females other than queen are always addressed together with men.

36 Use without the appellative is attested 23 times and use with it is attested 10 times in the corpus studied.

37 HKM 36b Vo 37-38. 
(6) BELU-mu aššul hatrešk-e namma-ššan ANA lord-me greeting write.DUR-2.SG.IMP further-on to É-YA IGI.HI.A-wa harak- $\varnothing$ house-1.SG.POSS eye.COLL-stem.NOM.COLL keep.2.SG.IMP 'Lord, keep writing me greetings and keep eyes on my house.'38

(7) UMMA ${ }^{\mathrm{D} U T U-S ̌ S}-M A \quad[A N A]$ MUNUS.LUGAL GAŠAN-YA thus ${ }^{\text {god }}$ sun-stem-COP to woman.king lady-my AMA.DÙG.GA-YA QIBI-MA mother.dear-my say-COP 'Thus His Majesty, say to the queen, my lady, my dear mother.'39

Lastly, the strategically polite and rare form of address should also be mentioned. It was used by state officials when communicating with the Hittite

Table 1: Address forms in Hittite state correspondence.

\begin{tabular}{|c|c|c|}
\hline \multicolumn{2}{|l|}{ Address terms } & \multirow{2}{*}{$\begin{array}{l}\text { Relative social status } \\
\text { (used for) }\end{array}$} \\
\hline title & & \\
\hline & + my lord/lady (+ my dear mother) & Sup, Sub \\
\hline \multirow[t]{5}{*}{ name } & & Sup, E, Sub \\
\hline & + my lord (and) my superior & Sup \\
\hline & + my dear father/mother & Sup \\
\hline & + my (dear) brother/sister & $\mathrm{E}$ \\
\hline & + my (dear) son/daughter & Sub \\
\hline \multirow{5}{*}{ title (+ name) } & & Sup \\
\hline & + my lord/lady/superior & Sup \\
\hline & + my dear father/mother & Sup \\
\hline & + my (dear) brother/sister & $\mathrm{E}$ \\
\hline & + my (dear) son/daughter & Sub \\
\hline \multirow[t]{4}{*}{$\begin{array}{l}\text { my lord } \\
\text { lord, lady }\end{array}$} & & Sup \\
\hline & + title & Sup \\
\hline & + (name) + my superior $/ m y$ dear father $/$ mother & Sup \\
\hline & + my lord/lady & Sup \\
\hline
\end{tabular}

38 HKM 27 23-24.

39 KBo 18.2 1-2. 
king..$^{40}$ It is a form of indirect address in which the addressee is named with a title and the $1^{\text {st }}$ person possessive pronoun; the verb is in the $3^{\text {rd }}$ person singular imperative form (8). As the following example of a greeting letter shows, this form of address is used when the sender is securing his relationship with His Majesty.
(8)

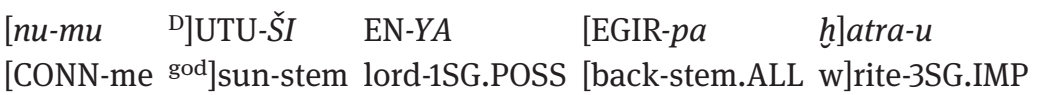 'May My Majesty, My lord write back to me.' ${ }^{41}$

The choice of address terms in Hittite state correspondence was thus affected by absolute social status (My Majesty), relative social status (marking in-group identity with my brother in symmetric or out-group identity with my lord in asymmetric relations), degree of social distance (marking a lesser degree of social distance with father or names and greater distance with lord or titles) and solidarity (the king addresses the queen with my lady and subordinates with names). The use of titles stressed authority and social power. This is also true for the indirect form of address, whereas personal names had an ambiguous function (they indicated the out-group identity of a subordinate or in-group identity of an equal).

\section{Self-presentation forms}

Superiors present themselves with a title and/or with a name. If the superior in question is the king or queen, only a title is used (1). ${ }^{42}$ In symmetric relations, a name is usually used, and this self-presentation is occasionally expanded with the appellative brother and the $2^{\text {nd }}$ person possessive pronoun (4). In the correspondence of high ranking officials, titles could be used by themselves (2). Subordinates present themselves with a name to which the appellatives servant (ARAD) or maid (GÉME) and the $2^{\text {nd }}$ person possessive pronoun are added. This self-presentation is used consistently by officials when addressing the king (9); the Hittite queen replaces her name with her title, but still uses

40 This was already noted by Hagenbuchner (1989a: 147). The author does not mention that this form of address appears in state correspondence only when addressing superiors; for addressing approximately equal communication participants it is used only in international correspondence, see for example KUB 21.38.

41 KBo 18.3 9'-10'.

42 Self-presentation of the Hittite king was already described by Hagenbuchner (1989a: 64). 
Table 2: Self-presentation forms in Hittite state correspondence.

\begin{tabular}{lll}
\hline Self-presentation terms & Relative social status (used by) \\
\hline title & + your servant/maid & Sup, E, Sub \\
& & Sub \\
name & + your brother/sister & E \\
& + your son & E \\
& + your servant/maid & Sub \\
& & Sub \\
title + name & + your maid & Sup \\
& & Sub \\
\hline
\end{tabular}

the appellative your maid, thus acknowledging the higher social status of the king (10). Self-presentation with the title your son (DUMU=KA) is occasionally attested. Its use is not limited to terms of address of the type my dear father, and the superior can also be addressed with my lord (5).43

In the body of the letters, $1^{\text {st }}$ person personal pronouns are used for selfpresentation; a notable exception are letters of the Hittite king, who often speaks of himself in the $3^{\text {rd }}$ person and presents himself with a title (11). These forms of self-presentation and their possible combinations are presented in Table 2.

(9) ANA DUTU-ŠI BELI-YA QIBI-MA UMMA m.DU-BELI

to ${ }^{\text {god }}$ sun-stem lord-my say-COP thus male Adad-beli

ARAD-KA-MA

servant-your.COP

'Say to His Majesty, my lord. Thus Adad-beli, your servant ...'44

(10) ANA DUTU-ŠI BELI-YA QIBI-MA UMMA MUNUS.LUGAL GÉME-[KA] to ${ }^{\text {god }}$ sun-stem lord-my say-COP thus woman.king maid.[-your]

'Say to His Majesty, my lord. Thus the queen, your maid ...' 45

43 The respectful term your daughter (DUMU.MUNUS =KA) is not attested in the Hittite letters published by Hagenbuchner (1989b), Alp (1991) and Hoffner (2009).

44 HKM 46 1-2.

45 Or. 90/800 Ro 1-2. 
(11) māhhhan-ta kāš tuppianza anda uemiyazzi nu MAHAR when-you this tablet in find.3.SG.IND CONN in front of DUTU-ŠI liliwahhuwanzi ūnni ${ }^{\text {god }}$ sun-stem hasten.INF drive.2.SG.IMP

'As soon as this tablet reaches you, drive quickly in the presence of My Majesty'. 46

The system of self-presentation in Hittite state correspondence mirrors, in a slightly less complex fashion, the system of address terms and is influenced by the same factors. The fact that self-presentation with the adjective dear, as in your dear brother, is not attested may have been influenced by the authors' wish not to impinge on addressees (in sense of Brown and Levinson 1987). Concern for the addressee's positive self-image is observable in the fact that the Hittites did not stress higher status, power and distance with self-presentation terms such as your lord, your father, 47 but captured these characteristics with titles that were neutral towards the addressee and that expressed absolute social status. Concern for the addressee's face thus seems to be a norm of deferential behavior in Hittite society. The unique impersonal self-presentation of the Hittite king is clearly motivated by his authority or role as an authorized speaker.

\section{Conclusions}

In Hittite state correspondence, the system of address and self-presentation terms and the address formula clearly reflect the writer's awareness of his place in society, as well as his desire to behave in conformity with culturally expected forms of behavior, and should be understood as ritualized performances for enacting social reality. From this point of view, the Hittites were a deferential society where relative and absolute social status played a crucial role in choosing appropriate linguistic expressions. Concern for the addressee's face is nevertheless reflected in the fact that the Hittites used exaltation of the other and self-humbling to strengthen the negative face of the addressee and neutral names and titles to maintain his positive face. Examples of real strategic politeness may be observed in symmetric relations where the writer is performing a

46 HKM 14 3-7.

47 This use is not attested in the letters published by Hagenbuchner (1989), Alp (1991) and Hoffner (2009). 
potentially face-threatening act and in some examples from letters to the Hittite king. The politeness approach utilized by Jucker (2010) thus explains the address and self-presentation terms as well as the use of the address formula in Hittite state correspondence quite perfectly, as real strategic and discernment politeness phenomena may be distinguished.

Acknowledgments: I would like to express my gratitude to the Fritz-Thyssen Stiftung for financially supporting part of this research from March to September 2013 and from May to December 2014. The research was conducted at the Institut für Assyriologie und Hethitologie, Ludwig-Maximilians-Universität München. I would like to thank J. Miller and W. Sallaberger for their help in obtaining financial aid and J. Miller for his willingness to again serve as my Betreuer.

\section{References}

Alp, Sedat. 1991. Hethitische Briefe aus Maşat - Höyük. Ankara: Türk Tarih Kurumu Basimevi.

Beal, Richard H. 1992. The organisation of the Hittite military. Heidelberg: Winter.

Beckman, Gary. 1995. Hittite provincial administration in Anatolia and Syria: The view from Maşat and Emar. In Onofrio Carruba, Mauro Giorgieri \& Celia Mora (eds.), Atti del II. congresso internazionale di hittitologia, 19-37. Pavia: Gianni luculano Editore.

Brown, Penelope \& Stephen Levinson. 1987. Politeness: Some universals in language usage. Cambridge: Cambridge University Press.

Bryce, Trevor. 2002. Life and society in the Hittite world. Oxford: Oxford University Press. Christie, Christine. 2007. Relevance theory and politeness. Journal of Politeness Research 3(2). 269-294.

Dik, Simon C. 1997. The theory of functional grammar. Part 1: The structure of the clause. Berlin \& New York: Mouton de Gruyter.

Edzard, Dietz O. 1976-1980. Keilschrift. In Edzard Dietz, Ernst Weidner \& Michael Streck (eds.), Reallexikon der Assyriologie und vorderasiatischen Archäologie 5, 544-568. Berlin \& New York: Walter de Gruyter.

Fillmore, Charles. 1997. Lectures on deixis. Stanford: Center for the Study of Language and Information.

Hagenbuchner, Albertine. 1989a. Die Korrespondenz der Hethiter. 1.Teil. Heidelberg: Winter. Hagenbuchner, Albertine. 1989b. Die Korrespondenz der Hethiter. 2.Teil. Heidelberg: Winter. Hoffner, Harry A. 2009. Letters from the Hittite Kingdom. Atlanta: Society of Biblical Literature.

Hoffner, Harry A. \& Craig Melchert. 2008. A grammar of the Hittite language. Indiana: Eisenbrauns.

Houwink ten Cate, Philo H. J. 1998. The scribes of the Maşat letters and the GAL DUB.SAR(.MEŠ) of the Hittite capital during the final phase of the early empire period. In Manfired Dietrich \& Oswald Loretz (eds.), Dubsar anta-men. Studien zur Altorienta- 
listik. Festschrift für Willem H. Ph. Römer zur Vollendung seines 70. Lebensjahres mit Beiträgen von Freunden, Schülern und Kollegen, 157-178. Münster: Ugarit-Verlag. Jucker, Andreas H. 2010. "In curteisie was set ful muchel hir lest.” Politeness in Middle English. In Jonathan Culpeper \& Dániel Z. Kádár (eds.), Historical (im)politeness, 175-200. Peter Lang: Bern.

Kádár, Dániel Z. \& Michael Haugh. 2013. Understanding politeness. Cambridge: Cambridge University Press.

Kasper, Gabriele. 1997. Linguistic etiquette. In Florian Coulmas (ed.), The handbook of sociolinguistics, 374-385. Oxford: Blackwell.

Klinger, Jörg. 1995. Das corpus der Maşat-Briefe und seine Beziehungen zu den Texten aus Hattuša. Zeitschrift für Assyriologie und vorderasiatische Archeologie 85. 74-108.

Klinger, Jörg. 2007. Die Hethiter. München: C. H. Beck.

Levinson, Stephen. C. 1994. Pragmatik. Tübingen: Niemeyer.

Marizza, Marco. 2007. Dignitari ittiti del tempo di Tuthaliya I/II, Arnuwanda I, Tuthaliya III. Firenze: LoGisma Editore.

Marizza, Marco. 2009. Lettere ittite di re e dignitari. Brescia: Paideia Editrice.

Mills, Sarah. 2011. Discursive approaches to politeness and impoliteness. In Linguistic Politeness Research Group (eds.), Discursive approaches to politeness, 19-56. Berlin \& Boston: Mouton de Gruyter.

Nevala, Minna. 2009. Altering distance and defining authority: Person reference in late modern English. Journal of Historical Pragmatics 10. 238-259.

van den Hout, Theo. 2007. Some observations on the tablet collection from Maşat Höyük. In Alfonso Archi \& Rita Francia (eds.), VI. Congresso Internazionale di Ittitologia Roma, 5-9 settembre 2005, Parte 1(Studi Micenei ed Egeo-Anatolici 49), 387-98.

van den Hout, Theo. 2008. A classified past: Classification of knowledge in the Hittite empire. In Robert D. Biggs, Jennie Myers \& Martha T. Roth (eds.), Proceedings of the $51^{\text {st }}$ Recontre Assyriologique Internationale (Held at the Oriental Institute of the University of Chicago July 18-22, 2005), 211-219. Chicago: The Oriental Institute.

van den Hout, Theo. 2009. Reflections on the origins and development of the Hittite tablet collections in Hattuša and their consequences for the rise of Hittite literacy. In Daddi Pecchioli Franca, Giulia Torri \& Carlo Corti (eds.), Central-north Anatolia in the Hittite period: New perspectives in light of recent research. Acts of the international conference held at the University of Florence (7-9 February 2007), 71-96. Roma: Herder.

von Schuler, Einar. 1957-1971. Gesellschaft. Bei den Hethitern. In Ernst Weidner \& Wolfram von Soden (eds.), Reallexikon der Assyriologie und vorderasiatischen Archäologie 3, 236-243. Berlin \& New York: Walter de Gruyter.

Watts, Richard J. 2005 Linguistic politeness research: Quo vadis?. In Richard J. Watts, Sachiko Ide \& Konrad Ehlich (eds.), Politeness in language, xi-xlvii. Berlin \& New York: Walter de Gruyter.

Weeden, Mark. 2014. State correspondence in the ancient world. In Karen Radner (ed.), State correspondence in the ancient world: From new kingdom Egypt to the Roman Empire, 32-63. Oxford: Oxford University Press. 


\section{Bionote}

\section{Mojca Cajnko}

Mojca Cajnko studied Ancient Greek, Hittite and General Linguistics at the Faculty of Arts at the University of Ljubljana in Slovenia and at the Ljubljana Graduate School of the Humanities. She first encountered politeness during her post-doctoral studies at LudwigMaximilians University in Munich. 